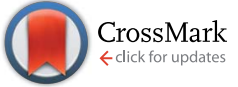

Cite this: J. Mater. Chem. A, 2017, 5 , 221

Received 21st October 2016 Accepted 22nd November 2016

DOI: 10.1039/c6ta09145h

www.rsc.org/MaterialsA

\title{
Solvent-free hierarchization of zeolites by carbochlorination $\uparrow$
}

\author{
Martin Nichterwitz, \$ Sven Grätz, \$ Winfried Nickel and Lars Borchardt* \\ Carbochlorination, a solvent-free top-down process, is a novel pathway for the hierarchization of zeolites. \\ In contrast to other methods no further washing steps are required. The employed method should serve as \\ a model system for the "upcycling" of coked and deactivated zeolites accumulated by the industry. In order \\ to establish a basic understanding of the process, zeolite $\mathrm{H}-\mathrm{Y}$ was taken as a model system and a thorough \\ investigation of important reaction parameters, like chlorination temperature, time and concentration, \\ carbon loading, and Si/Al ratio, was performed. Under optimized conditions, we have been able to \\ hierarchize $\mathrm{H}-\mathrm{Y}$ with high yield, doubling the mesopore volume while maintaining the crystallinity and \\ surface area.
}

\section{Introduction}

Zeolites are microporous, crystalline aluminosilicates that are widely used as heterogeneous catalysts, ${ }^{\mathbf{1 - 4}}$ catalyst supports, ion-exchangers, ${ }^{7}$ molecular sieve membranes, ${ }^{\mathbf{8}, \mathbf{9}}$ in the catalytic conversion of biomass ${ }^{\mathbf{1 0 - 1 2}}$ and many more advanced applications. ${ }^{13}$ Their final performance in all of the mentioned applications strongly depends on the accessibility of the active sites, which is largely affected by pore size and pore connectivity. ${ }^{\mathbf{1 4 , 1 5}}$ Diffusion limitations within these pores can lead to severe issues such as hindered mass transport, pore blocking, and especially in the field of heterogeneous catalysts, the formation of coke. This causes a decreasing catalytic activity and lifetime as well as undesirable product selectivities. ${ }^{\mathbf{1 6}}$ Hierarchization, the incorporation of an additional transport system into the material, can overcome these obstacles and enhance the diffusion and mass flow properties of a zeolite material. ${ }^{17-27}$ Several synthesis routes are known for hierarchical zeolites, which are usually classified as bottom-up or top-down methods. ${ }^{17-19,23,26,28,29}$ Bottom-up approaches commonly apply hard- or soft-templates, which serve as a placeholder for the future secondary porosity, directly into the synthesis of the zeolite framework. ${ }^{23,30}$ Commonly carbon nanomaterials ${ }^{31-35}$ but also organic aerogels, ${ }^{36}$ salts such as $\mathrm{CaCO}_{3}$ (ref. 37) or biological templates ${ }^{38}$ have been used as hard-templates, while structure-directing agents (SDA) such as surfactants are applied as soft-templates. ${ }^{\mathbf{3 9}, 40}$ Non-templating synthesis relies on aggregation of nanocrystals, ${ }^{\mathbf{4 1 , 4 2}}$ the crystallization of amorphous gels ${ }^{\mathbf{4 3}}$ or modification of crystal growth

Inorganic Chemistry, TU Dresden, Bergstrasse 66, D-01062 Dresden, Germany. E-mail: lars.borchardt@tu-dresden.de

$\dagger$ Electronic supplementary information (ESI) available: Further material characterization. See DOI: 10.1039/c6ta09145h

\$ Both authors contributed equally. direction..$^{23}$ However, upscaling and industrial implementation of most of these approaches is difficult due to high production costs that arise from the expensive template nanostructures, long synthesis time, including the necessary post-synthesis template removal, or the fact that some approaches are only applicable to a few zeolite structures. ${ }^{23,30}$ Top-down approaches, in turn, are based on post-synthesis treatments with acids and bases that leech either atoms ( $\mathrm{Si}$ or $\mathrm{Al}$ ) or fragments out of the framework, consequently creating mesopores. With dealumination $^{\mathbf{4 4 - 4 6}}$ by acids, and desilication ${ }^{47,48}$ by $\mathrm{NaOH}$ or organic hydroxides two main modification routes exist. However, many of the existing top-down methods require one or multiple washing steps, what makes this process time-consuming and waste-producing. The material loss during etching strongly depends on the applied etching agents, but it is often in the range of $\sim 50 \%{ }^{49}$ There are only a few publications reporting on the hierarchization preventing huge materials loss. ${ }^{50,51}$ In this respect particularly solvent-free methods have been developed allowing to synthesize and modify porous materials such as metal organic frameworks ${ }^{52-54}$ and zeolites. ${ }^{55}$

Here we present a radical new approach for the hierarchization of zeolites that is based on a one-step gas phase reaction (eqn (1) and (2)). This reaction, a carbochlorination, is known from the Kroll-process, the industrial process commonly used for the synthesis of titanium metal at temperatures between 750 and $1000{ }^{\circ} \mathrm{C} . .^{56,57}$

$$
\begin{gathered}
\mathrm{Al}_{2} \mathrm{O}_{3(\mathrm{~s})}+3 \mathrm{C}_{(\mathrm{s})}+3 \mathrm{Cl}_{2(\mathrm{~g})} \rightarrow 2 \mathrm{AlCl}_{3(\mathrm{~g})}+3 \mathrm{CO}_{(\mathrm{g})} \\
\mathrm{SiO}_{2(\mathrm{~s})}+2 \mathrm{C}_{(\mathrm{s})}+2 \mathrm{Cl}_{2(\mathrm{~g})} \rightarrow \mathrm{SiCl}_{4(\mathrm{~g})}+2 \mathrm{CO}_{(\mathrm{g})}
\end{gathered}
$$

We utilized zeolite $\mathrm{Y}$ as model system because it is one of the most important heterogeneous catalysts in petrochemical industry, e.g. in fluid catalytic cracking (FCC) and hydrocracking. ${ }^{58}$ 


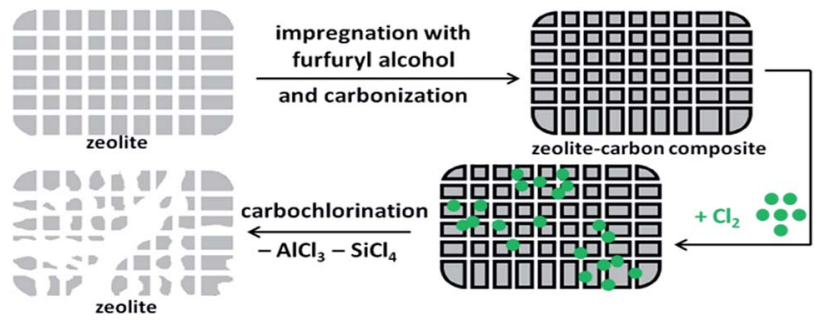

Fig. 1 Reaction scheme for solvent-free hierarchization of zeolite $Y$ by carbochlorination.

This approach is in addition motivated by the idea to re-use coked and deactivated zeolites accumulating after a catalytic reaction. Hot chlorine gas in combination with the deposited carbon (coke) inside the zeolite framework will lead to etching of $\mathrm{Si}$ and $\mathrm{Al}$ species (eqn (1) and (2)) and thus the generation of mesoporosity (Fig. 1). No post-synthesis washing steps are required and the yield is higher as compared to traditional top-down approaches. To study this approach systematically, defined amounts of carbon were brought into the material by infiltration and pyrolysis of furfuryl alcohol (FA). We investigated the influence of different parameters such as chlorination temperature, reaction time, carbon concentration, $\mathrm{Si} / \mathrm{Al}$ ratio and chlorine concentration on the porosity, hierarchization, crystallinity, and acidity of the resulting zeolites. We have shown that a high amount of mesoporosity can be introduced while ensuring a low material loss.

\section{Experimental section}

\section{Zeolite-carbon composite synthesis}

$5 \mathrm{~g}$ of commercially available zeolite H-Y (CBV 400, Zeolyst International, $\mathrm{SiO}_{2}$ to $\mathrm{Al}_{2} \mathrm{O}_{3}$ molar ratio: 5.1, specific surface area: $730 \mathrm{~m}^{2} \mathrm{~g}^{-1}$; CBV 901, Zeolyst International, $\mathrm{SiO}_{2}$ to $\mathrm{Al}_{2} \mathrm{O}_{3}$ molar ratio: 80 , specific surface area: $700 \mathrm{~m}^{2} \mathrm{~g}^{-1}$ ) were impregnated with $2 \mathrm{~mL}$ solution of furfuryl alcohol (FA) and ethanol (EtOH) by mixing with mortar and pestle for $15 \mathrm{~min}$. The composition of each solution is shown in Table 1 . The infiltrated zeolite was carbonized under argon flow $(>110 \mathrm{~mL}$ $\min ^{-1}$ ) with several temperature steps.

Samples were treated for $2 \mathrm{~h}$ at room temperature, then heated for $24 \mathrm{~h}$ at $80^{\circ} \mathrm{C}$ (heating rate $60 \mathrm{~K} \mathrm{~h}^{-1}$ ), further for $8 \mathrm{~h}$ at $150{ }^{\circ} \mathrm{C}$ (heating rate $60 \mathrm{~K} \mathrm{~h}^{-1}$ ) and finally for $4 \mathrm{~h}$ at $600{ }^{\circ} \mathrm{C}$ (heating rate: $300 \mathrm{~K} \mathrm{~h}^{-1}$ ).

\section{Carbochlorination}

The black zeolite-carbon-composites were flushed under argon atmosphere $\left(150 \mathrm{~mL} \mathrm{~min}^{-1}\right)$ for $30 \mathrm{~min}$, followed by heating to the reaction temperature (heating rate $450 \mathrm{~K} \mathrm{~h}^{-1}$ ). Subsequently, the gas flow was changed to a mixture of $10 \mathrm{~mL} \mathrm{~min}{ }^{-1}$ chlorine and 70 or $110 \mathrm{~mL} \mathrm{~min}^{-1}$ argon while the temperature was kept for $2 \mathrm{~h}, 4 \mathrm{~h}$ or $8 \mathrm{~h}$, respectively. Then, the samples were cooled/heated from the reaction temperature $\left(400-900{ }^{\circ} \mathrm{C}\right)$ to $600{ }^{\circ} \mathrm{C}$ under argon flow for $1 \mathrm{~h}$ and finally treated with

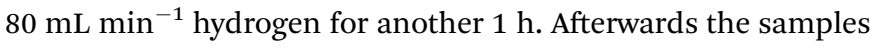
were cooled down to room temperature under argon.
Table 1 Preparation of zeolite-carbon composites

\begin{tabular}{lllll}
\hline Sample & Zeolite & $V_{\mathrm{FA}} / \mathrm{mL}$ & $V_{\mathrm{EtOH}} / \mathrm{mL}$ & $V_{\left(\mathrm{FA} m_{\text {zeolite }}\right.}{ }^{-1} / \mathrm{mL} \mathrm{g}^{-1}$ \\
\hline Composite 1 (C1) & HY-5 & 0.25 & 1.75 & 0.05 \\
Composite 2 (C2) & HY-5 & 0.50 & 1.50 & 0.10 \\
Composite 3 (C3) & HY-5 & 1.00 & 1.00 & 0.20 \\
Composite 4 (C4) & HY-80 & 0.25 & 1.75 & 0.05 \\
Composite 5 (C5) & HY-80 & 0.50 & 1.50 & 0.10 \\
Composite 6 (C6) & HY-80 & 1.00 & 1.00 & 0.20
\end{tabular}

\section{Sample nomenclature}

The sample name consists of its reaction parameters and has the following structure: $\mathrm{C} \alpha-\beta-\gamma-\delta / \varepsilon$, where $\mathrm{C} \alpha$ is the composite, $\beta$ is the reaction temperature in ${ }^{\circ} \mathrm{C}, \gamma$ is the reaction time in $\mathrm{h}$, $\delta$ is the chlorine flow in $\mathrm{mL} \min ^{-1}$ and $\varepsilon$ is the argon flow in $\mathrm{mL}$ $\min ^{-1}$. For example, C1-500-4-10/70 means a carbochlorination of composite 1 at $500{ }^{\circ} \mathrm{C}$ for $4 \mathrm{~h}$ with a gas mixture of chlorine $\left(10 \mathrm{~mL} \mathrm{~min}^{-1}\right)$ and argon $\left(70 \mathrm{~mL} \mathrm{~min}^{-1}\right)$.

\section{Calcination}

Before temperature-programmed ammonia desorption (TPAD) or inductively coupled plasma optical emission spectrometry (ICP-OES) measurements, some samples were additionally calcined under air for $6 \mathrm{~h}$ at $550{ }^{\circ} \mathrm{C}\left(10 \mathrm{~K} \mathrm{~min}^{-1}\right)$.

\section{Characterization}

The argon physisorption was measured at $-186{ }^{\circ} \mathrm{C}$ on an Autosorb iQ (Quantachrome Instruments) after vacuum activation at $300{ }^{\circ} \mathrm{C}$ for $16 \mathrm{~h}$. Specific surface areas $\left(\mathrm{SSA}_{\mathrm{BET}}\right)$ were evaluated using the multipoint BET equation according to the criteria stated from Rouquerol et al. ${ }^{59}$ Pore size distributions (PSDs) were calculated using the non-local density functional theory (NLDFT) method (adsorption branch kernel) for argon adsorbed on zeolites/silica with a cylindrical/spherical pore shape at $-186^{\circ} \mathrm{C}$. This kernel was also used to calculate specific surface area $\left(\mathrm{SSA}_{\mathrm{DFT}}\right)$, total pore volumes $\left(\mathrm{PV}_{\mathrm{DFT}}\right)$, micropore volume $\left(\mathrm{PV}_{\text {micro,DFT }}, d_{\text {pore }}<2 \mathrm{~nm}\right)$ and mesopore volume (PV $\left.\mathrm{PV}_{\text {meso,DFT }}, d_{\text {pore }} 2-50 \mathrm{~nm}\right)$.

Nitrogen physisorption experiments were operated at $-196^{\circ} \mathrm{C}$ on a Quadrasorb evo (Quantachrome Instruments). Total pore volumes $\left(\mathrm{PV}_{\text {total }}\right)$ were determined at $p / p_{0}=0.95$. The $t$-plot method $\left(p / p_{0}=0.2-0.5\right)$ was used to determine the micropore volume $\left(\mathrm{PV}_{\text {micro }}\right)$ and external surface area $\left(S_{\mathrm{EXT}}\right)$. Determination of specific surface areas $\left(\mathrm{SSA}_{\mathrm{BET}}\right)$ was done similar to argon physisorption. Nitrogen physisorption isotherms were measured after vacuum activation at $230{ }^{\circ} \mathrm{C}$ for $2 \mathrm{~h}$.

Powder X-ray diffraction (XRD) measurements were performed on a XPERT PRO (PANanalytics) using $\mathrm{Cu} \mathrm{K} \alpha$ radiation as fourfold determination in the $2 \theta$ range $5-50^{\circ}$ and $0.026^{\circ}$ step width. The crystallinity was estimated according to the standardized procedure ASTM D 3906-03. ${ }^{60}$ Therefore the area of the $15.7^{\circ}, 18.7^{\circ}, 20.4^{\circ}, 23.7^{\circ}, 27.1^{\circ}, 30.8^{\circ}, 31.5^{\circ}$ and $34.2^{\circ} 2 \theta$ reflections (equivalent to the [331], [511], [440], [533], [642], [822], [555] and [664] hkl planes, respectively) were taken after 
background subtraction in relation to the starting material HY (CBV 400, Zeolyst Int.).

Acidity was investigated with temperature-programmed ammonia desorption (TPAD) using a Belcat Basic (BEL Japan, Inc.) in the temperature range from 100 to $700{ }^{\circ} \mathrm{C}$. Samples (around $40 \mathrm{mg}$ ) were activated at $500{ }^{\circ} \mathrm{C}\left(10 \mathrm{~K} \mathrm{~min}^{-1}\right)$ for one hour under $\mathrm{He}\left(50 \mathrm{~mL} \mathrm{~min}^{-1}\right)$ and then cooled down to $100{ }^{\circ} \mathrm{C}$. After cooling the sample was loaded with pure ammonia $(50 \mathrm{~mL}$ $\mathrm{min}^{-1}$ ) for $30 \mathrm{~min}$. Desorption of physisorbed ammonia was performed by streaming with $\mathrm{He}\left(50 \mathrm{~mL} \mathrm{~min}{ }^{-1}\right)$ at $100{ }^{\circ} \mathrm{C}$ for $5 \mathrm{~h}$. The chemisorbed ammonia was desorbed by heating the sample from $100{ }^{\circ} \mathrm{C}$ to $700{ }^{\circ} \mathrm{C}\left(10 \mathrm{~K} \mathrm{~min}^{-1}\right)$ under constant $\mathrm{He}$ flow $\left(20 \mathrm{~mL} \mathrm{~min}^{-1}\right)$.

Thermogravimetric (TG) and mass spectroscopy (MS) measurements were carried out with STA 409 PC Luxx (NETZSCH) under synthetic air $\left(80 \% \mathrm{~N}_{2}, 20 \% \mathrm{O}_{2}\right)$ from 25 to $1250{ }^{\circ} \mathrm{C}$ with a heating rate of $5 \mathrm{~K} \mathrm{~min}^{-1}$. The amount of residual carbon $\left(C_{\text {res }}\right)$ is calculated by the difference of weight loss between 400 to $800{ }^{\circ} \mathrm{C}$ from the zeolite-carbon composite to the carbochlorinated sample.

Scanning electron microscopy (SEM) images of gold sputtered samples were performed using a DSM-982 Gemini (Zeiss) with a magnification of 50000 and $6 \mathrm{kV}$ acceleration voltage.

Optical emission spectroscopy (ICP-OES) measurements on an Optima 7000DV (Perkin Elmer) indicated the Si and $\mathrm{Al}$ content in the samples. Si ratio was measured with a radial detector $(251.611 \mathrm{~nm})$ and $\mathrm{Al}$ concentration in axial position $(396.153 \mathrm{~nm})$. Digestion of around $10 \mathrm{mg}$ sample was performed with $150 \mu \mathrm{L} \mathrm{HNO}_{3}, 150 \mu \mathrm{L} \mathrm{HF}$ and $150 \mu \mathrm{L} \mathrm{HCl}$ in a microwave at $130^{\circ} \mathrm{C}$ (ramp: $5 \mathrm{~min}$ ) for $15 \mathrm{~min}$. Afterwards complexation with $1.5 \mathrm{~mL}$ saturated boric acid was realized as well in a microwave at $130{ }^{\circ} \mathrm{C}$ (ramp: $5 \mathrm{~min}$ ) for $15 \mathrm{~min}$.

\section{Results and discussion}

The proof of principle of this new hierarchization strategy is based on a commercially available zeolite H-Y which was impregnated with furfuryl alcohol. After coking, a defined gas mixture of chlorine and argon was applied to study the hierarchization process. First, the influence of chlorination temperature on porosity and textural properties of the hierarchical material is discussed. In continuing sections, the influence of carbon content, chlorination time, chlorine concentration, and Si/Al-ratio will be discussed.

\section{Chlorination temperature}

Hierarchization was performed at five different temperatures from 400 to $800{ }^{\circ} \mathrm{C}$ on carbon-zeolite-composite 2, which has a carbon content of about $7.26 \mathrm{w} \%$ (determined by TG-MS). All samples were treated for $4 \mathrm{~h}$ with a gas mixture of $10 \mathrm{~mL} \mathrm{~min}^{-1}$ chlorine and $70 \mathrm{~mL} \min ^{-1}$ argon. With higher reaction temperature, the hierarchization evolves and the amount of created mesopores increases. The Ar-physisorption measurement (Fig. 2) of the parent material (H-Y 5 pure) shows a type I isotherm characteristic for materials with almost exclusive microporous character. With higher chlorination temperatures the isotherms show increasing gas uptake in the $p / p_{0}$ range from 0.6 to 0.8 . The isotherm shape turns into type IV exhibiting a large hysteresis, which is typical for mesoporous materials. We can state that with higher chlorination temperature the total pore volume as well as the mesopore volume increases, while the micropore volume decreases. Consequently we can observe an increase in the $\mathrm{SSA}_{\mathrm{EXT}}$ as well (Table 2). This trend reaches a maximum for $700^{\circ} \mathrm{C}$ with $0.40 \mathrm{~cm}^{3} \mathrm{~g}^{-1}$ total pore volume, but brakes down at $800{ }^{\circ} \mathrm{C}$ where the sample shows a lower total pore volume $\left(0.29 \mathrm{~cm}^{3} \mathrm{~g}^{-1}\right)$. The sample treated at $400{ }^{\circ} \mathrm{C}$ shows the lowest total pore volume $\left(0.23 \mathrm{~cm}^{3} \mathrm{~g}^{-1}\right)$ due to the high content of residual carbon within the pore network. At low temperatures (e.g. $\left.400{ }^{\circ} \mathrm{C}\right)$ the etching is less efficient while at too high temperature $\left(>800{ }^{\circ} \mathrm{C}\right)$ the destruction of the zeolite system becomes excessive. This effect is also reflected by the decrease of the specific surface area with the increase in chlorination temperature (Table 2).

Verboekend et al. introduced the hierarchical factor (HF), which is defined as a product of the relative micropore volume $\left(V_{\text {micro }} / V_{\text {total }}\right)$ and the relative mesopore surface area $\left(S_{\text {meso }} / \mathrm{SSA}\right) .{ }^{61}$ Its purpose is to characterize hierarchization efficiency. Carbochlorination of composite 2 shows a good hierarchization performance at $500{ }^{\circ} \mathrm{C}$ with an increased $\mathrm{HF}$ of 0.050. As against at higher reaction temperatures the $\mathrm{HF}$ decreases to 0.031 for $700{ }^{\circ} \mathrm{C}$ and 0.038 for $800{ }^{\circ} \mathrm{C}$ due to an excessive introduction of mesopore volume.

Moreover, the chlorination temperature not only influences the amount of mesoporosity but also the pore size distribution of the hierarchical zeolites (Fig. 3). With an increase of reaction temperature the pore size is shifted to larger pore widths. Samples at $400{ }^{\circ} \mathrm{C}$ and $500{ }^{\circ} \mathrm{C}$ already show some pores with a diameter of 4 and $7 \mathrm{~nm}$, respectively. For $600^{\circ} \mathrm{C}$, a broadening of the pore size distribution with pores from 6 to $16 \mathrm{~nm}$ is observed, while samples at 700 and $800{ }^{\circ} \mathrm{C}$ show two main pore sizes about 10 and $16 \mathrm{~nm}$ (Fig. 3b).

The effect of a more intense etching reaction at higher temperatures can also be seen on SEM images. Fig. 4a shows the

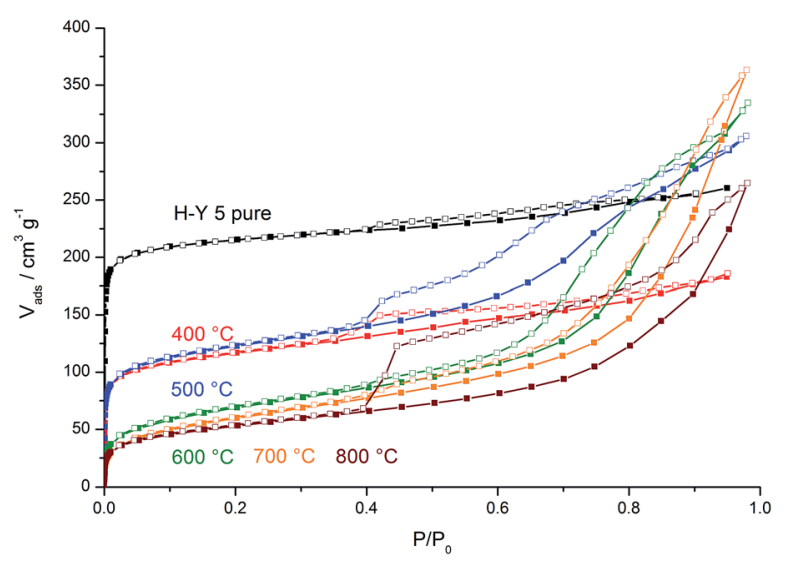

Fig. 2 Ar physisorption isotherms at $-186{ }^{\circ} \mathrm{C}$ for samples of composite $2\left(0.10 \mathrm{~mL} \mathrm{~g}^{-1}\right)$ carbochlorinated at different temperatures. Samples: $400{ }^{\circ} \mathrm{C}(\mathrm{C} 2-400-4-10 / 70), 500{ }^{\circ} \mathrm{C}$ (C2-500-4-10/70), $600{ }^{\circ} \mathrm{C}(\mathrm{C} 2-600-4-10 / 70), 700{ }^{\circ} \mathrm{C}$ (C2-700-4-10/70), $800{ }^{\circ} \mathrm{C}$ (C2-800-4-10/70). 
Table 2 Characterization data of carbochlorinated samples at different temperatures. Physisorption data derived from Ar-isotherms measured at $-186^{\circ} \mathrm{C}$

\begin{tabular}{|c|c|c|c|c|c|c|c|c|c|c|c|}
\hline Sample $^{a}$ & $\begin{array}{l}\mathrm{Si} / \mathrm{Al}^{b} / \\
\mathrm{mol} \mathrm{mol}^{-1}\end{array}$ & $\begin{array}{l}\mathrm{SSA}_{\mathrm{BET}}{ }^{c} / \\
\mathrm{m}^{2} \mathrm{~g}^{-1}\end{array}$ & $\begin{array}{l}\mathrm{SSA}_{\mathrm{EXT}}^{d} / \\
\mathrm{m}^{2} \mathrm{~g}^{-1}\end{array}$ & $\begin{array}{l}\mathrm{PV}_{\text {total }}{ }^{e} / \\
\mathrm{cm}^{3} \mathrm{~g}^{-1}\end{array}$ & $\begin{array}{l}\mathrm{PV}_{\text {micro }}{ }^{d} / \\
\mathrm{cm}^{3} \mathrm{~g}^{-1}\end{array}$ & $\begin{array}{l}\mathrm{PV}_{\text {meso }} f_{/} \\
\mathrm{m}^{3} \mathrm{~g}^{-1}\end{array}$ & $\mathrm{HF}^{g}$ & $C_{\mathrm{XRD}}{ }^{h} / \%$ & $\begin{array}{l}\text { Total acidity }{ }^{i} / \\
\text { mmol g }^{-1}\end{array}$ & $C_{\mathrm{res}}^{j} / \mathrm{w} \%$ & Yield $^{k} / \mathrm{w} \%$ \\
\hline H-Y 5 pure & 3.0 & 751 & 72 & 0.33 & 0.29 & 0.12 & 0.015 & 100 & 0.995 & - & - \\
\hline C2-500-4-10/70 & 7.0 & 378 & 169 & 0.37 & 0.13 & 0.27 & 0.050 & 51 & 0.394 & 2.82 & 76 \\
\hline C2-600-4-10/70 & 18.3 & 214 & 161 & 0.39 & 0.04 & 0.37 & 0.038 & 22 & 0.227 & 0.71 & 72 \\
\hline $\mathrm{C} 2-700-4-10 / 70$ & 13.9 & 189 & 163 & 0.40 & 0.03 & 0.41 & 0.031 & 19 & 0.195 & 1.28 & 67 \\
\hline
\end{tabular}

${ }^{a}$ Sample description given in Experimental section. ${ }^{b}$ ICP-OES elemental analysis. ${ }^{c}$ Multi-point BET-method. ${ }^{d} t$-Plot method $p / p_{0}$ from 0.2 to 0.5 . ${ }^{e}$ Total pore volume at $p / p_{0}=0.95 .{ }^{f} \mathrm{PV}_{\text {meso }}=\mathrm{PV}_{\text {total }}-\mathrm{PV}_{\text {micro }}{ }^{g}$ Hierarchy factor $\mathrm{HF}=\left(\mathrm{PV}_{\text {micro }} / \mathrm{PV}_{\text {total }}\right)\left(S_{\mathrm{EXT}} / \mathrm{SSA}_{\mathrm{BET}}\right) .^{61}{ }^{h} \% \mathrm{XRD}$ intensity/HY after ASTM 3906-03. ${ }^{60} i$ Total acidity determined by TPAD. ${ }^{j}$ Residual carbon $\left(C_{\mathrm{res}}\right)$ analyzed by TG; $C_{\mathrm{res}}=C_{\mathrm{sample}}-C_{\mathrm{H}-\mathrm{Y}} 5$ pure. ${ }^{k}$ Calculated by weighing before and after carbochlorination.

parent material with intact crystals. From Fig. $4 \mathrm{~b}$ to d (corresponding to 400,500 and $600{ }^{\circ} \mathrm{C}$ ) we observe increasing leaching effects on the edges and faces of the crystals.

Nevertheless, the particle morphology and integrity remains conserved. Fig. 4e and $\mathrm{f}\left(700\right.$ and $\left.800{ }^{\circ} \mathrm{C}\right)$ however show heavily attacked faces and edges after the carbochlorination. This destructive effect on the zeolite framework at higher temperatures is also visible in the powder XRDs (Fig. 5), where we notice a broadening of reflexes for 400 and $500{ }^{\circ} \mathrm{C}$ and a more and more amorphous signal from 17 to $30^{\circ} 2 \theta$ for the samples synthesized at 600,700 and $800^{\circ} \mathrm{C}$. This trend can be quantified by the decreasing relative crystallinity with respect to that of $\mathrm{H}-\mathrm{Y} 5$ shown in Table 2. Although the main reflex [111] at $6^{\circ} 2 \theta$ is visible in the whole temperature range, the relative crystallinity calculated from eight main reflexes according to ASTM D 3906-03 (ref. 60) $\left(15.7^{\circ}, 18.7^{\circ}, 20.4^{\circ}, 23.7^{\circ}, 27.1^{\circ}, 30.8^{\circ}, 31.5^{\circ}\right.$ and $34.2^{\circ} 2 \theta$ ) decreases to $46 \%$ at $400{ }^{\circ} \mathrm{C}$ and $22 \%$ at $800{ }^{\circ} \mathrm{C}$. The similar trend is observed for the total acidity, measured by TPAD (Fig. 6), that decreases with increasing reaction temperatures. The total acidity decreases from $69 \%$ at $400{ }^{\circ} \mathrm{C}$, to $40 \%$ at $500{ }^{\circ} \mathrm{C}$ down to $18 \%$ at $800{ }^{\circ} \mathrm{C}$ compared to the parent material (H-Y 5 pure). In addition ICP-OES measurements state out that with increasing chlorination temperature the molar $\mathrm{Si}$ to $\mathrm{Al}$
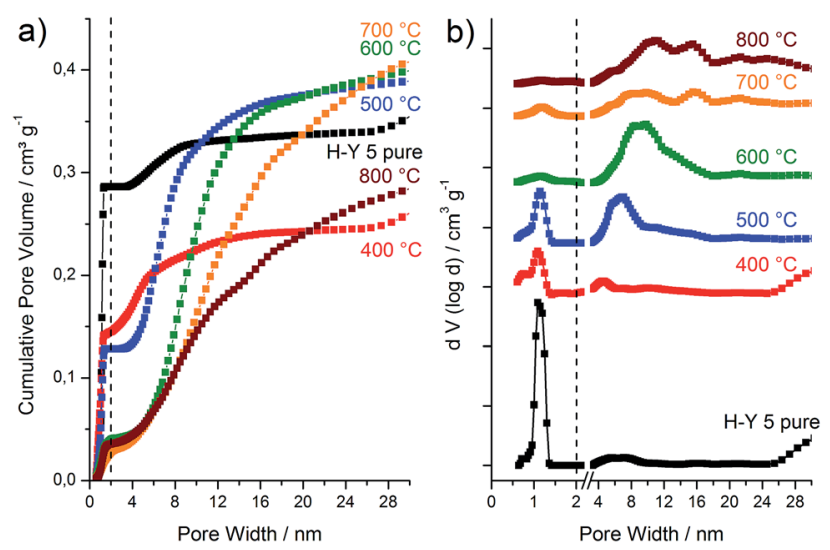

Fig. 3 (a) Cumulative pore volume (b) $\mathrm{d} V(\log d)$ pore size distribution calculated with NLDFT (adsorption branch kernel) from argon isotherms (Fig. 2) ratio increases from 3.0 (H-Y untreated) to $18.3\left(600{ }^{\circ} \mathrm{C}\right)$ and then decreases to $8.7\left(800{ }^{\circ} \mathrm{C}\right)$. This implies that at lower temperatures $\left(<600{ }^{\circ} \mathrm{C}\right)$ preferably $\mathrm{Al}$-species are etched from the framework (dealumination). This process can be easily followed using ${ }^{29} \mathrm{Si}$ CP-MAS NMR (Fig. S1 $\dagger$ ), where a decrease of $\mathrm{Si}(n \mathrm{Al})$-species can be observed. Furthermore, by employing ${ }^{27} \mathrm{Al}$ CP-MAS NMR (Fig. S2 $\dagger$ ) it can be shown, that the leeched aluminum is not deposited as extra-framework species but removed completely. The evidence of which is the increasing ratio of $\mathrm{Al}^{\mathrm{Va}}$ to $\mathrm{Al}^{\mathrm{VI}}$. At higher temperature $\left(>600^{\circ} \mathrm{C}\right) \mathrm{Al}$-species seem to be less favored and Si-species are etched in higher amount (desilication), however, there is still less $\mathrm{Al}$ than in the starting material. Dealumination at temperatures below $600^{\circ} \mathrm{C}$ corresponds to the significant decrease of total acidity in TPAD likely caused by the elimination, of tetrahedral Al-species. Over
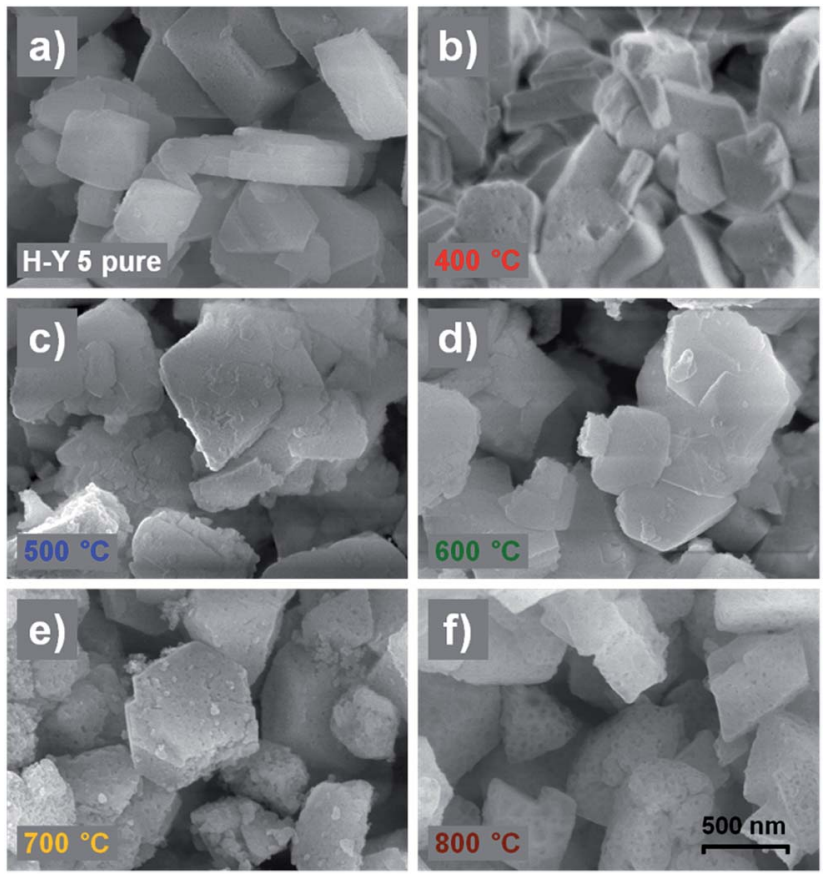

Fig. 4 SEM images of carbochlorinated samples from composite 2 at temperatures from 400 to $800{ }^{\circ} \mathrm{C}$. 


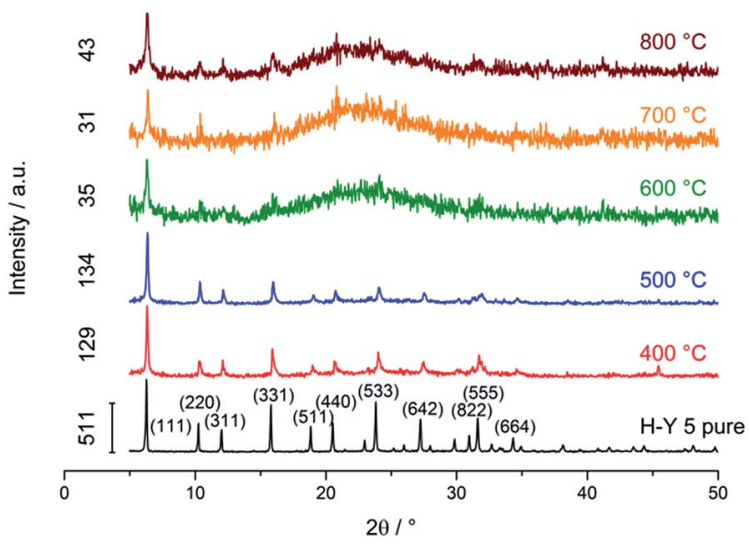

Fig. 5 XRD from carbochlorinated composite 2 samples (like in Fig. 2). Diffractograms are normalized on the main reflex [111] at $6^{\circ} 2 \theta$. The absolute intensity of the [331] reflex is given on the left.

$600{ }^{\circ} \mathrm{C}$, the total acidity decreases further due to dealumination and more loss of Si-species (e.g. silanol-groups, threefold Si).

In general with higher temperatures a stronger reaction takes place. This progress leads to decreasing residual carbon contents because more carbon is used during the reaction (eqn (1) and (2)). The composite contains $7.26 \mathrm{w} \%$ carbon and the concentration of residual carbon decreases from $7.17 \mathrm{w} \%$ at $400{ }^{\circ} \mathrm{C}$ down to $0.55 \mathrm{w} \%$ at $800{ }^{\circ} \mathrm{C}$. Regarding the loss of carbon and framework species it is reasonable that the yield decreases with higher temperatures from $94 \mathrm{w} \%\left(400^{\circ} \mathrm{C}\right)$ to $71 \mathrm{w} \%\left(800^{\circ} \mathrm{C}\right)$.

Summing up, etching at $400{ }^{\circ} \mathrm{C}$ and $500{ }^{\circ} \mathrm{C}$ is favoured due to increased mesoporosity, $\mathrm{HF}$, high yield, a moderate decrease in microporosity, total acidity and still intact crystallinity as represented in Table 2. Here it should be noticed that the increasing $\mathrm{Si} / \mathrm{Al}$ ratio and the loss of acidity can even be beneficial for certain applications.

\section{Carbon content in composite}

The impact of the carbon content within the zeolite micropore framework is investigated based on three different carbonzeolite-composites (Table 1), which were pyrolyzed with different FA loadings. These three composites C1, C2 and C3 correspond to carbon loadings of around 3.0, 7.3 and $14.1 \mathrm{w} \%$ carbon investigated by TG analysis, shown in Fig. S3. $\dagger$ The $\mathrm{N}_{2}$-physisorption isotherms (Fig. S4 $\dagger$ ) of the samples treated at $500{ }^{\circ} \mathrm{C}$ show type IV isotherms and an increase of mesopore volume from 0.19 (C1-500-4-10/70) to $0.30 \mathrm{~cm}^{3} \mathrm{~g}^{-1}$ (C3-500-4-10/70), small differences in micropore volumes and therefore also an increase of total pore volume and HF with higher carbon loadings. Further $\mathrm{N}_{2}$-adsorption for samples treated at $400{ }^{\circ} \mathrm{C}$ and $600{ }^{\circ} \mathrm{C}$ (Fig. S5 and S6 $\dagger$ ) is provided in the ESI. $\dagger$ At a temperature of $400{ }^{\circ} \mathrm{C}$ the sample with the highest carbon loading shows the lowest $\mathrm{N}_{2}$-isotherm uptake, this can be explained by the high residual carbon content in the pore network (Fig. S5 $\dagger$ ). Sample C3-500-4-10/70, derived from composite 3 with 14 w\% carbon loading shows the most promising results with slightly higher SSA $\left(565 \mathrm{~m}^{2} \mathrm{~g}^{-1}\right)$, pore volume $\left(0.44 \mathrm{~cm}^{3} \mathrm{~g}^{-1}\right)$, mesopore volume $\left(0.3 \mathrm{~cm}^{3} \mathrm{~g}^{-1}\right)$, hierarchy factor $(0.13)$ and remaining total acidity

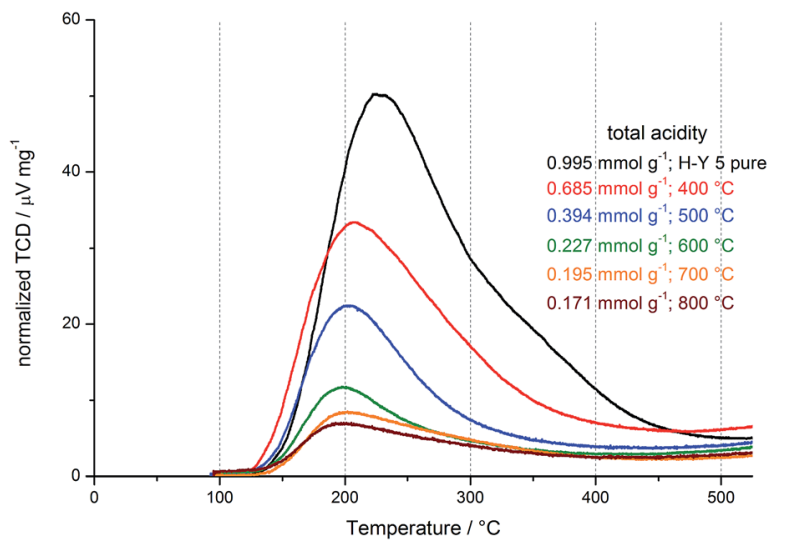

Fig. 6 TPAD of all composite 2 samples synthesized at different temperatures and calcinated under air at $550{ }^{\circ} \mathrm{C}$ for 6 .

$\left(0.639 \mathrm{mmol} \mathrm{g}^{-1}\right)$. This higher mesopores volume is caused by the higher carbon ratio in the composite that in turn causes a stronger leaching of framework species.

In general, we can state that higher carbon content leads to a more intense reaction and likewise slightly higher mesopore volumes and increasing $\mathrm{HF}$ (Table 3). Comparable to the previous section higher chlorination temperatures again increases total and mesopore volume but decreases micropore volume, total acidity, and crystallinity. The gain of mesopores at higher carbon contents results in a lower crystallinity, which was already seen in Fig. 5. All three triples (C1, C2, C3 at $400{ }^{\circ} \mathrm{C}$, $500{ }^{\circ} \mathrm{C}$ and $600{ }^{\circ} \mathrm{C}$ ) show this effect (Fig. S8 $\dagger$ ). The total acidity, investigated by TPAD, shows especially for lower temperatures $\left(400{ }^{\circ} \mathrm{C}\right.$ : (Fig. S8†), $500{ }^{\circ} \mathrm{C}$ : (Fig. 7)) no big differences, thus the loss of acidic centers corresponds mostly to the chlorination temperature and not to the carbon content. However, at $600{ }^{\circ} \mathrm{C}$ TPAD shows a certain decrease of total acidity with higher carbon contents (Fig. S9†). Further characterization, presented in Table 3 shows an increasing molar $\mathrm{Si} / \mathrm{Al}$ ratio with increasing carbon contents. Thus, the reaction with Al-species seems to be preferred over Si-species. For all three temperatures, the residual carbon content increases from composite 1 to composite 3 , likely caused by the higher initial carbon content. In contrast, samples derived from the same composite and therefore same initial carbon loading show a diminution of residual carbon with increasing temperature. All samples were produced with high yields about 70 to $90 \%$. Only the composite 3 sample at $600{ }^{\circ} \mathrm{C}(\mathrm{C} 3-600-4-10 / 70)$ shows a smaller $58 \%$ yield caused by a strong reaction and an increased loss of framework material. We can summarize that higher carbon contents lead to a higher hierarchization and therefore higher mesoporosity, total pore volume and hierarchy factor. This can be explained, by a more exhaustive leaching of Al- and Si-species corresponding to eqn (1) and (2). Whereas the crystallinity is reduced by higher carbon ratios the total acidity is retained. The SSA is preserved or even slightly increased for higher carbon contents.

\section{Chlorination time}

Fig. S10 $\uparrow$ shows the $\mathrm{N}_{2}$-physisorption isotherms of samples prepared from composite 2 that have been carbochlorinated at 
Table 3 Characterization data of samples out of all three different composites (C1, C2 and C3) at 400,500 and $600{ }^{\circ} \mathrm{C}$. Physisorption data derived from $\mathrm{N}_{2}$-isotherms measured at $-196{ }^{\circ} \mathrm{C}$

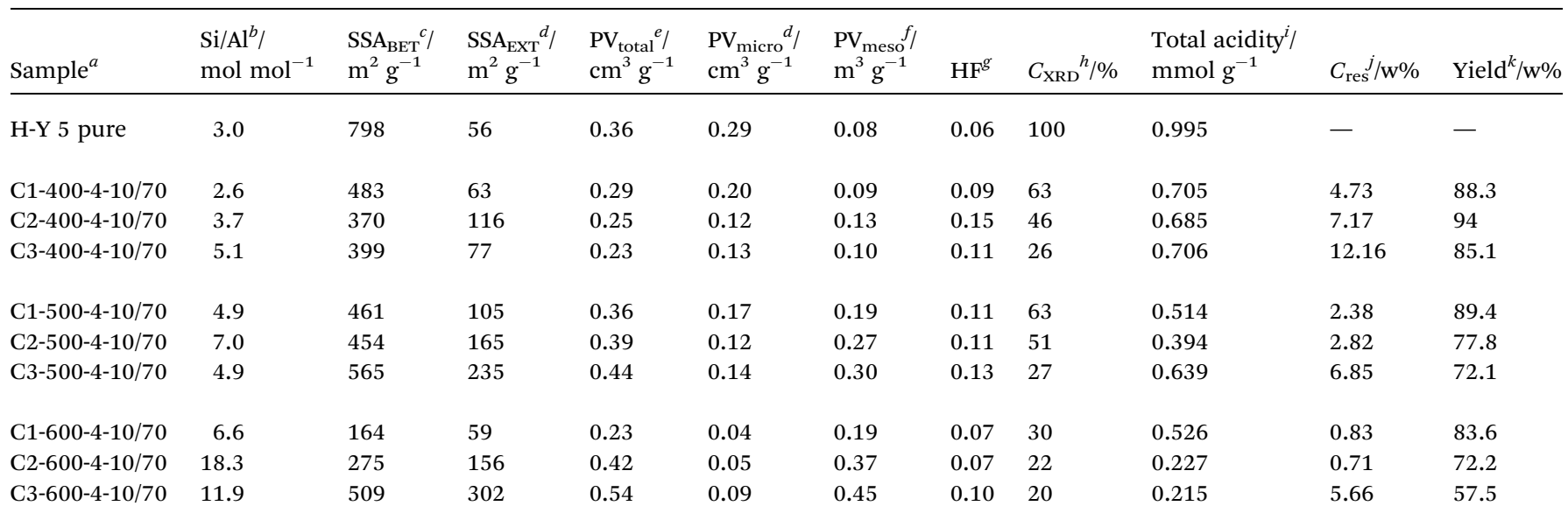

${ }^{a}$ Sample description given in Experimental section. ${ }^{b}$ ICP-OES elemental analysis. ${ }^{c}$ Multi-point BET-method. ${ }^{d} t$-Plot method $p / p_{0}$ from 0.2 to 0.5 . ${ }^{e}$ Total pore volume at $p / p_{0}=0.95 .{ }^{f} \mathrm{PV}_{\text {meso }}=\mathrm{PV}_{\text {total }}-\mathrm{PV}_{\text {micro. }}{ }^{g}$ Hierarchy factor $\mathrm{HF}=\left(\mathrm{PV}_{\text {micro }} / \mathrm{PV}_{\text {total }}\right)\left(S_{\mathrm{EXT}} / \mathrm{SSA}_{\mathrm{BET}}\right) .{ }^{61}{ }^{h} \% \mathrm{XRD}$ intensity/HY after ASTM 3906-03. ${ }^{60}{ }^{i}$ Total acidity determined by TPAD. ${ }^{j}$ Residual carbon $\left(C_{\mathrm{res}}\right)$ analyzed by TG; $C_{\mathrm{res}}=C_{\mathrm{sample}}-C_{\mathrm{H}-\mathrm{Y}} 5$ pure. ${ }^{k}$ Calculated by weighing before and after carbochlorination.

$400{ }^{\circ} \mathrm{C}$ and $500{ }^{\circ} \mathrm{C}$ for 2,4 , and $8 \mathrm{~h}$, respectively. The $\mathrm{N}_{2^{-}}$ isotherms at $400{ }^{\circ} \mathrm{C}$ and $500{ }^{\circ} \mathrm{C}$ are nearly superimposed. Similar result can also be seen for the samples at $600{ }^{\circ} \mathrm{C}$ (Fig. S11†).

Thus, the reaction time seems to have no significant influence on the porosity (Fig. S10 $\dagger$ ) and acidity (Fig. S11†), as TPAD and $\mathrm{N}_{2}$-adsorption show similar values (Table 4). The XRD measurements (Fig. S13 ${ }^{\dagger}$ ) show comparable crystallinity for samples synthesized at $500{ }^{\circ} \mathrm{C}$ or $600{ }^{\circ} \mathrm{C}$ for $2 \mathrm{~h}$ and $4 \mathrm{~h}$, respectively. Nevertheless to long reaction times lead to decreasing crystallinity and $\mathrm{HF}$, as seen for $8 \mathrm{~h}$ at $500{ }^{\circ} \mathrm{C}$ (C2-500-8-10/70). In contrast the $400{ }^{\circ} \mathrm{C}$ samples show an increase of total acidity and crystallinity from $4 \mathrm{~h}$ to $8 \mathrm{~h}$ reaction time. A possible reason can be the reinsertion of Al-species in the framework over time under this relatively mild conditions and therefore the rebuilding of acidic sites, as the $\mathrm{Si} / \mathrm{Al}$ ratio increases similar to the total acidity. The yields are comparable for different reaction times at the same reaction temperature, whereas the residual carbon content decreases with increasing reaction time. All material characteristics are summarized in Table 4.

\section{Chlorine concentration}

Few investigations with different chlorine concentration were performed. Higher chlorine concentration leads to a stronger hierarchization with an increased total and mesopore volume (Fig. S14 $\dagger$ ). However, we can also observe a decreased crystallinity and a lower total acidity of the samples (Fig. S15 and $\mathrm{S} 16 \dagger$ ). All characterization data is provided in ESI (Table S1†).

\section{$\mathrm{Si} / \mathrm{Al}$ ratio}

In addition to the parameters discussed above we also investigated the influence of the $\mathrm{Si} / \mathrm{Al}$ ratio on the chlorination process. With a $\mathrm{Si} / \mathrm{Al}$ ratio of 40 , the $\mathrm{HY}-80$ presents a steep increase in this parameter but it inherently possesses a few mesopores owing to the fabrication process. Due to the decreased aluminum content, the hierarchization requires higher temperatures. This is in accordance with findings from the ICP-OES (Table 2). In the experiments, beneficial effects on the adsorption behavior can be observed at $800{ }^{\circ} \mathrm{C}$ to $900{ }^{\circ} \mathrm{C}$ (Table 5 and Fig. S17†). Temperatures higher than these lead to an excessive destruction of the zeolite network and hence a drastic decrease in surface area and pore volume of the material. The impact of the reduced aluminum content can also be observed in the TPAD measurements. Where the HY-5 loses nearly $83 \%$ of its acidity during the treatment at $800{ }^{\circ} \mathrm{C}$ the HY-80 loses only $28 \%$ under the same conditions. More interestingly, even at the higher temperatures, the zeolite maintains most of its crystallinity (Table 5 and Fig. S18 $\dagger$ ). This is in sharp contrast to HY-5 (Fig. 5).

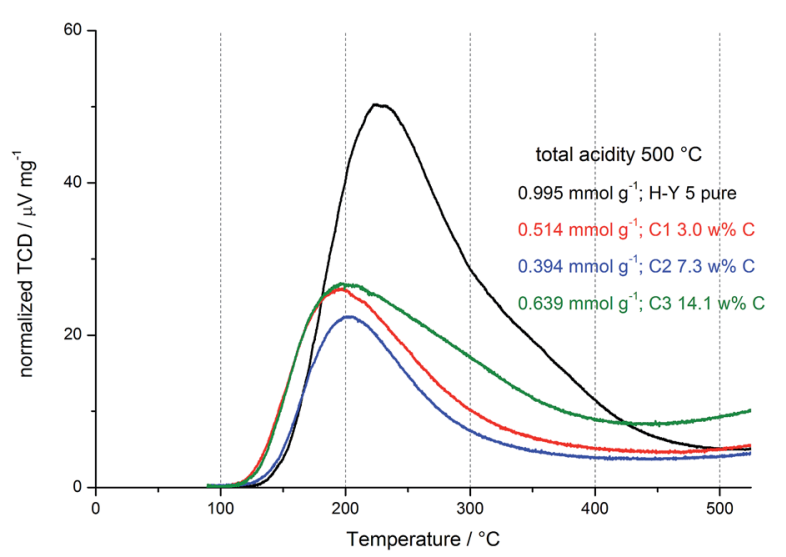

Fig. 7 TPAD of all three composite samples after carbochlorination at $500{ }^{\circ} \mathrm{C}$ and calcination. C1-500-4-10/70 (red), C2-500-4-10/70 (blue), C3-500-4-10/70 (green). 
Table 4 Characterization data of samples synthesized at 400,500 and $600{ }^{\circ} \mathrm{C}$ for different reaction times. Physisorption data derived from $\mathrm{N}_{2}-$ isotherms measured at $-196^{\circ} \mathrm{C}$

\begin{tabular}{|c|c|c|c|c|c|c|c|c|c|c|c|}
\hline Sample $^{a}$ & $\begin{array}{l}\mathrm{Si} / \mathrm{Al}^{b} / \\
\mathrm{mol} \mathrm{mol}^{-1}\end{array}$ & $\begin{array}{l}\mathrm{SSA}_{\mathrm{BET}}{ }^{\mathrm{c}} / \\
\mathrm{m}^{2} \mathrm{~g}^{-1}\end{array}$ & $\begin{array}{l}\mathrm{SSA}_{\mathrm{EXT}}{ }^{d} / \\
\mathrm{m}^{2} \mathrm{~g}^{-1}\end{array}$ & $\begin{array}{l}\mathrm{PV}_{\text {total }}{ }^{e} / \\
\mathrm{cm}^{3} \mathrm{~g}^{-1}\end{array}$ & $\begin{array}{l}\mathrm{PV}_{\text {micro }}{ }^{d} / \\
\mathrm{cm}^{3} \mathrm{~g}^{-1}\end{array}$ & $\begin{array}{l}\mathrm{PV}_{\text {meso }} f_{/} \\
\mathrm{m}^{3} \mathrm{~g}^{-1}\end{array}$ & $\mathrm{HF}^{g}$ & $C_{\mathrm{XRD}}{ }^{h} / \%$ & $\begin{array}{l}\text { Total acidity }{ }^{i} / \\
\text { mmol }^{-1}\end{array}$ & $C_{\mathrm{res}}^{j} / \mathrm{w} \%$ & Yield $^{k} / \mathrm{w} \%$ \\
\hline H-Y 5 pure & 3.0 & 798 & 56 & 0.36 & 0.29 & 0.08 & 0.056 & 100 & 0.995 & - & - \\
\hline $\mathrm{C} 2-400-4-10 / 70$ & 3.7 & 370 & 116 & 0.25 & 0.12 & 0.13 & 0.155 & 46 & 0.685 & 7.17 & 94.0 \\
\hline C2-400-8-10/70 & 2.9 & 381 & 87 & 0.24 & 0.14 & 0.10 & 0.137 & 67 & 0.882 & 7.63 & 99.3 \\
\hline $\mathrm{C} 2-500-8-10 / 70$ & n.a. & 381 & 182 & 0.42 & 0.08 & 0.34 & 0.093 & 35 & 0.393 & 1.72 & 72.6 \\
\hline $\mathrm{C} 2-600-2-10 / 70$ & 15.8 & 228 & 158 & 0.44 & 0.04 & 0.40 & 0.066 & 22 & 0.242 & 1.45 & 69.2 \\
\hline $\mathrm{C} 2-600-4-10 / 70$ & 18.3 & 275 & 156 & 0.42 & 0.05 & 0.37 & 0.070 & 22 & 0.227 & 0.71 & 72.2 \\
\hline
\end{tabular}

${ }^{a}$ Sample description given in Experimental section. ${ }^{b}$ ICP-OES elemental analysis. ${ }^{c}$ Multi-point BET-method. ${ }^{d} t$-Plot method $p / p_{0}$ from 0.2 to 0.5 . ${ }^{e}$ Total pore volume at $p / p_{0}=0.95 .{ }^{f} \mathrm{PV}_{\text {meso }}=\mathrm{PV}_{\text {total }}-\mathrm{PV}_{\text {micro }}{ }^{g}$ Hierarchy factor $\mathrm{HF}=\left(\mathrm{PV}_{\text {micro }} / \mathrm{PV}_{\text {total }}\right)\left(S_{\mathrm{EXT}} / \mathrm{SSA} \mathrm{BET}_{\mathrm{BET}}\right){ }^{61}{ }^{h} \% \mathrm{XRD}$ intensity/HY after ASTM 3906-03. ${ }^{60} i$ Total acidity determined by TPAD. ${ }^{j}$ Residual carbon $\left(C_{\text {res }}\right)$ analyzed by TG; $C_{\text {res }}=C_{\text {sample }}-C_{\mathrm{H}-\mathrm{Y}} 5$ pure. ${ }^{k}$ Calculated by weighing before and after carbochlorination.

Table 5 Characterization data of the $\mathrm{H}-\mathrm{Y} 80$ samples. Physisorption data derived from $\mathrm{N}_{2}$-isotherms measured at $-196^{\circ} \mathrm{C}$

\begin{tabular}{|c|c|c|c|c|c|c|c|c|c|c|c|}
\hline Sample $^{a}$ & $\begin{array}{l}\mathrm{Si} / \mathrm{Al}^{b} / \\
\mathrm{mol} \mathrm{mol}^{-1}\end{array}$ & $\begin{array}{l}\mathrm{SSA}_{\mathrm{BET}}{ }^{c} / \\
\mathrm{m}^{2} \mathrm{~g}^{-1}\end{array}$ & $\begin{array}{l}\mathrm{SSA}_{\mathrm{EXT}}{ }^{d} / \\
\mathrm{m}^{2} \mathrm{~g}^{-1}\end{array}$ & $\begin{array}{l}\mathrm{PV}_{\text {total }}^{e} / \\
\mathrm{cm}^{3} \mathrm{~g}^{-1}\end{array}$ & $\begin{array}{l}\mathrm{PV}_{\text {micro }}{ }^{d} / \\
\mathrm{cm}^{3} \mathrm{~g}^{-1}\end{array}$ & $\begin{array}{l}\mathrm{PV}_{\text {meso }} f_{/} \\
\mathrm{m}^{3} \mathrm{~g}^{-1}\end{array}$ & $\mathrm{HF}^{g}$ & $C_{\mathrm{XRD}}^{h} / \%$ & $\begin{array}{l}\text { Total acidity }{ }^{i} / \\
\text { mmol g }^{-1}\end{array}$ & $C_{\mathrm{res}}^{j} / \mathrm{w} \%$ & Yield $^{k} /$ w\% \\
\hline H-Y 80 pure & 34.6 & 738 & 143 & 0.45 & 0.24 & 0.21 & 0.103 & 100 & 0.108 & - & - \\
\hline C5-500-4-10/70 & n.a. & 582 & 109 & 0.44 & 0.23 & 0.21 & 0.096 & 76 & 0.097 & 5.09 & 98.6 \\
\hline C5-600-4-10/70 & n.a. & 585 & 99 & 0.44 & 0.24 & 0.21 & 0.086 & 76 & 0.081 & 4.55 & 98.4 \\
\hline C5-800-4-10/70 & 46.1 & 617 & 240 & 0.53 & 0.19 & 0.34 & 0.130 & 76 & 0.078 & 1.17 & 88.9 \\
\hline C4-800-4-10/70 & 50.0 & 753 & 218 & 0.50 & 0.22 & 0.28 & 0.121 & 92 & 0.057 & 0.52 & 91.0 \\
\hline C5-800-4-10/70 & 46.1 & 617 & 240 & 0.53 & 0.19 & 0.34 & 0.130 & 76 & 0.078 & 1.17 & 88.9 \\
\hline C6-800-4-10/70 & 38.5 & 817 & 288 & 0.68 & 0.22 & 0.47 & 0.111 & 87 & 0.055 & 1.48 & 73.8 \\
\hline
\end{tabular}

${ }^{a}$ Sample description given in Experimental section. ${ }^{b}$ ICP-OES elemental analysis. ${ }^{c}$ Multi-point BET-method. ${ }^{d} t$-Plot method $p / p_{0}$ from 0.2 to 0.5 . ${ }^{e}$ Total pore volume at $p / p_{0}=0.95 .{ }^{f} \mathrm{PV}_{\text {meso }}=\mathrm{PV}_{\text {total }}-\mathrm{PV}_{\text {micro. }}{ }^{g}$ Hierarchy factor $\mathrm{HF}=\left(\mathrm{PV}_{\text {micro }} / \mathrm{PV}_{\text {total }}\right)\left(S_{\mathrm{EXT}} / \mathrm{SSA}_{\mathrm{BET}}\right) .^{61} h \% \mathrm{XRD}$ intensity/HY after ASTM $3906-03 .{ }^{60} i$ Total acidity determined by TPAD. ${ }^{j}$ Residual carbon $\left(C_{\text {res }}\right)$ analyzed by TG; $C_{\text {res }}=C_{\text {sample }}-C_{\mathrm{H}-\mathrm{Y}} 5$ pure. ${ }^{k}$ Calculated by weighing before and after carbochlorination.

A variation of the carbon content was undertaken in the same fashion as for the HY-5, the results of which are presented in the lower half of Table 5. These three composites C4, C5 and C6 correspond to carbon loadings of around 3.6, 6.5 and $9.3 \mathrm{w} \%$ carbon as determined by TG analysis (Fig. S19†). The $\mathrm{N}_{2}$-physisorption isotherms (Fig. 8) for the samples treated at $800{ }^{\circ} \mathrm{C}$ show type IV isotherms and an increase of mesopore volume from 0.28 (C4-800-4-10/70) to $0.47 \mathrm{~cm}^{3} \mathrm{~g}^{-1}$ (C6-800-4-10/70) and therefore also an increase of total pore volume with higher carbon loadings. Sample C6-500-4-10/70, derived from composite 6 with $9.3 \mathrm{w} \%$ carbon loading shows the most promising results with a higher SSA $\left(817 \mathrm{~m}^{2} \mathrm{~g}^{-1}\right)$, pore volume $\left(0.68 \mathrm{~cm}^{3} \mathrm{~g}^{-1}\right)$, mesopore volume $\left(0.47 \mathrm{~cm}^{3} \mathrm{~g}^{-1}\right)$, hierarchy factor (0.111) and remaining total acidity $\left(0.055 \mathrm{mmol} \mathrm{g}^{-1}\right)$. The higher carbon ratio in the composite causes a stronger leaching of framework species and thereby creates a higher mesopore volume. In contrary to the HY-5 samples the crystallinity of all

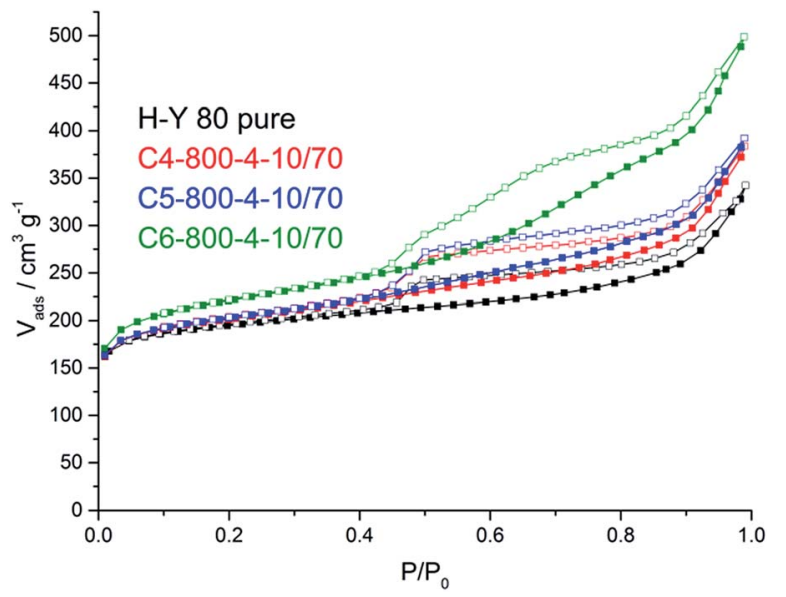

Fig. $8 \mathrm{~N}_{2}$-Isotherms at $-196{ }^{\circ} \mathrm{C}$ of samples at $800{ }^{\circ} \mathrm{C}$ from different zeolite-carbon composite red (C4-500-4-10/70), blue (C5-500-410/70), green (C6-500-4-10/70). 


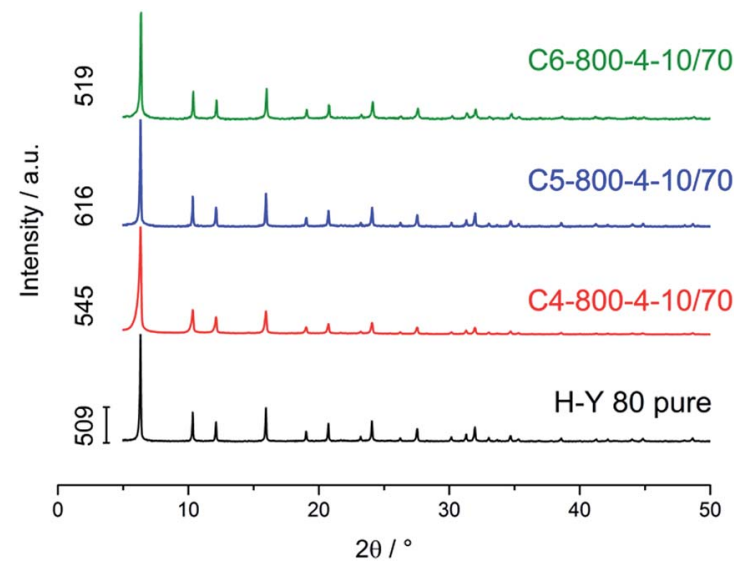

Fig. 9 XRD of carbochlorinated composite samples. Diffractograms are normalized on the main reflex [111] at $6^{\circ} 2 \theta$. The absolute intensity of the [331] reflex is given on the left.

3 samples remains on a high level (Fig. 9) and the acidity only drops to $51 \%$ (C6-800-4-10/70) to $72 \%$ (C5-800-4-10/70) of the parent zeolite with no clear trend visible in these samples (Fig. S20 $\dagger$ ). ICP-OES shows a lower Si/Al ratio with increasing carbon contents (Table 5) level. It can be deduced that at higher carbon loadings the leachable aluminium species are depleted and therefore the leeching silica species takes place and reduces the $\mathrm{Si} / \mathrm{Al}$ ratio. This trend correlates with the yield of the three samples which is between 91\% (C4-800-4-10/70) and 73.8\% (C6-800-4-10/70). For all three different temperatures, the residual carbon content increases from composite 4 to composite 6 caused by the higher initial carbon content. We can summarize that higher carbon contents lead to higher hierarchization and therefore higher mesoporosity, total pore volume. Compared to HY-5 the crystallinity is mostly retained after the treatment and the SSA is kept or even increased for higher carbon contents.

\section{Conclusions}

As the first proof of principle, we presented a new top-down synthesis route for hierarchical zeolite Y. The process of carbochlorination has no need for any solvents and can be executed in a one-step reaction.

The herein used zeolite/carbon composite material should serve as a model system for coked and deactivated zeolite Y. It was the scope of this research to elucidate the hierarchization process in-depth, rather than screening different zeolite types or giving potential applications for hierarchical zeolites.

Our experiments show that carbochlorination temperature and carbon loading are the most influencing parameters to tune the properties of hierarchical zeolite. The insights obtained from the experiments with HY-5 could be adapted to the different $\mathrm{Si} / \mathrm{Al}$ ratio of $\mathrm{HY}-80$ as well, by changing the treatment temperature.

A chlorination temperature of $500{ }^{\circ} \mathrm{C}(\mathrm{HY}-5)$ or $800{ }^{\circ} \mathrm{C}$ (HY-80) respectively and high carbon content was best with respect to generated mesoporosity, with only a moderate loss in total acidity and retained crystallinity.
The best results were obtained with HY-80, where the treatment leads to a doubling of the pore volume while the surface area and crystallinity of the material could be maintained.

Carbochlorination yields materials with a 1.5 to 1.75 times higher hierarchy factor (HF) and around 40 to $70 \mathrm{w} \%$ of initial total acidity with a yield from 70 to $94 \mathrm{w} \%$ compared to an industrially available zeolite $\mathrm{Y}$ material. We can state the following findings.

(1) Higher carbochlorination temperatures lead to a stronger hierarchization with higher hierarchy factors and meso-/ micropore volume ratios, reduced crystallinity, decreased SSA, and lower total acidity.

(2) The $\mathrm{Si} / \mathrm{Al}$ ratio plays a major role in the carbochlorination behavior of zeolites, with higher ratios making for a higher crystallinity and meso-/micropore volume ratios, a similar or higher SSA, and a lower total acidity.

(3) Higher initial carbon contents lead to stronger hierarchization.

(4) Increasing reaction time did not significantly impact porosity, total acidity, SSA or yield. Only some differences in crystallinity and residual carbon occur.

\section{Acknowledgements}

We gratefully acknowledge the Federal Ministry of Education and Research (Bundesministerium für Bildung und Forschung, BMBF) for support of the Mechanocarb project (award number 03SF0498). The authors acknowledge Anja Werner for support with TPD measurements and Silvia Paasch for support with the NMR measurements.

\section{Notes and references}

1 W. Vermeiren and J. P. Gilson, Top. Catal., 2009, 52, 11311161.

2 E. T. C. Vogt and B. M. Weckhuysen, Chem. Soc. Rev., 2015, 44, 7342-7370.

3 C. Martínez and A. Corma, Coord. Chem. Rev., 2011, 255, 1558-1580.

4 B. Yilmaz and U. Müller, Top. Catal., 2009, 52, 888-895.

5 Q. Lin, G. Yang, Q. Chen, R. Fan, Y. Yoneyama, H. Wan and N. Tsubaki, ChemCatChem, 2015, 7, 682-689.

6 T. Moteki, Y. Murakami, S. Noda, S. Maruyama and T. Okubo, J. Phys. Chem. C, 2011, 115, 24231-24237.

7 T. Humplik, J. Lee, S. C. O'Hern, B. a. Fellman, M. A. Baig, S. F. Hassan, M. A. Atieh, F. Rahman, T. Laoui, R. Karnik and E. N. Wang, Nanotechnology, 2011, 22, 292001.

8 K. Varoon, X. Zhang, B. Elyassi, D. D. Brewer, M. Gettel, S. Kumar, J. A. Lee, S. Maheshwari, A. Mittal, C.-Y. Sung, M. Cococcioni, L. F. Francis, A. V. McCormick, K. A. Mkhoyan and M. Tsapatsis, Science, 2011, 334, 72-75.

9 Y. Morigami, M. Kondo, J. Abe, H. Kita and K. Okamoto, Sep. Purif. Technol., 2001, 25, 251-260.

10 T. P. Vispute, H. Zhang, A. Sanna, R. Xiao and G. W. Huber, Science, 2010, 330, 1222-1227. 
11 U. Olsbye, S. Svelle, M. Bjørgen, P. Beato, T. V. W. Janssens, F. Joensen, S. Bordiga and K. P. Lillerud, Angew. Chem., Int. Ed., 2012, 51, 5810-5831.

12 T. Ennaert, J. Van Aelst, J. Dijkmans, R. De Clercq, W. Schutyser, M. Dusselier, D. Verboekend and B. F. Sels, Chem. Soc. Rev., 2016, 45, 584-611.

13 J. Pérez-Ramírez, Nat. Chem., 2012, 4, 250-251.

14 Y. Wei, T. E. Parmentier, K. P. de Jong and J. Zečević, Chem. Soc. Rev., 2015, 44, 7234-7261.

15 M. Milina, S. Mitchell, N. L. Michels, J. Kenvin and J. PérezRamírez, J. Catal., 2013, 308, 398-407.

16 M. Argyle and C. Bartholomew, Catalysts, 2015, 5, 145-269. 17 K. Zhang and M. L. Ostraat, Catal. Today, 2016, 264, 3-15.

18 D. Verboekend, N. Nuttens, R. Locus, J. Van Aelst, P. Verolme, J. C. Groen, J. Pérez-Ramírez and B. F. Sels, Chem. Soc. Rev., 2015, 45(12), 8093.

19 J. Pérez-Ramírez, C. H. Christensen, K. Egeblad, C. H. Christensen and J. C. Groen, Chem. Soc. Rev., 2008, 37, 2530-2542.

20 J. C. Groen, W. Zhu, S. Brouwer, S. J. Huynink, F. Kapteijn, J. A. Moulijn and J. Pérez-Ramírez, J. Am. Chem. Soc., 2007, 129, 355-360.

21 R. Lakes, Nature, 1993, 361, 511-515.

22 S. Mitchell, N.-L. Michels, K. Kunze and J. Pérez-Ramírez, Nat. Chem., 2012, 4, 825-831.

23 W. Schwieger, A. G. Machoke, T. Weissenberger, A. Inayat, T. Selvam, M. Klumpp and A. Inayat, Chem. Soc. Rev., 2015, 45, 3353-3376.

24 X. Wei and P. G. Smirniotis, Microporous Mesoporous Mater., 2006, 97, 97-106.

25 L. Zhao, B. Shen, J. Gao and C. Xu, J. Catal., 2008, 258, 228-234. 26 K. Möller and T. Bein, Chem. Soc. Rev., 2013, 42, 3689-3707.

27 J. Jiang, J. L. Jorda, J. Yu, L. a. Baumes, E. Mugnaioli, M. J. Diaz-Cabanas, U. Kolb and A. Corma, Science, 2011, 333, 1131-1134.

28 D. Verboekend, G. Vilé and J. Pérez-Ramírez, Adv. Funct. Mater., 2012, 22, 916-928.

29 D. P. Serrano, J. M. Escola and P. Pizarro, Chem. Soc. Rev., 2013, 42, 4004-4035.

30 D. Verboekend and J. Pérez-Ramírez, ChemSusChem, 2014, 7, 753-764.

31 I. Schmidt, A. Boisen, E. Gustavsson, K. Ståhl, S. Pehrson, S. Dahl, A. Carlsson and C. J. H. Jacobsen, J. Am. Chem. Soc., 2000, 13, 4416-4418.

32 C. J. H. Jacobsen, C. Madsen, J. Houzvicka, I. Schmidt and A. Carlsson, J. Am. Chem. Soc., 2000, 122, 7116-7117.

33 H. S. Cho and R. Ryoo, Microporous Mesoporous Mater., 2012, 151, 107-112.

34 W. Fan, M. Snyder, S. Kumar, P.-S. Lee, W. C. Yoo, A. V. McCormick, R. Lee Penn, A. Stein and M. Tsapatsis, Nat. Mater., 2008, 7, 984-991.

35 Y. Tao, H. Kanoh and K. Kaneko, J. Am. Chem. Soc., 2003, 125, 6044-6045.

36 W. Li, A.-H. Lu, R. Palkovits, W. Schmidt, B. Spliethoff and F. Schüth, J. Am. Chem. Soc., 2005, 127, 12595-12600.

37 H. Zhu, Z. Liu, Y. Wang, D. Kong, X. Yuan and Z. Xie, Chem. Mater., 2008, 20, 1134-1139.
38 A. Zampieri, G. T. P. Mabande, T. Selvam, W. Schwieger, A. Rudolph, R. Hermann, H. Sieber and P. Greil, Mater. Sci. Eng., C, 2006, 26, 130-135.

39 Y. Zhu, Z. Hua, J. Zhou, L. Wang, J. Zhao, Y. Gong, W. Wu, M. Ruan and J. Shi, Chem. - Eur. J., 2011, 17, 14618-14627.

40 A. Inayat, I. Knoke, E. Spiecker and W. Schwieger, Angew. Chem., Int. Ed., 2012, 51, 1962-1965.

41 Z. Wang, C. Li, H. J. Cho, S.-C. Kung, M. a. Snyder and W. Fan, J. Mater. Chem. A, 2015, 3, 1298-1305.

42 H. Awala, J.-P. Gilson, R. Retoux, P. Boullay, J.-M. Goupil, V. Valtchev and S. Mintova, Nat. Mater., 2015, 14, 447-451.

43 B. Li, Z. Hu, B. Kong, J. Wang, W. Li, Z. Sun, X. Qian, Y. Yang, W. Shen, H. Xu and D. Zhao, Chem. Sci., 2014, 5, 1565.

44 A. Gola, B. Rebours, E. Milazzo, J. Lynch, E. Benazzi, S. Lacombe, L. Delevoye and C. Fernandez, Microporous Mesoporous Mater., 2000, 40, 73-83.

45 J. A. van Bokhoven, D. C. Koningsberger, P. Kunkeler, H. van Bekkum and A. P. M. Kentgens, J. Am. Chem. Soc., 2000, 122, 12842-12847.

46 M. Müller, G. Harvey and R. Prins, Microporous Mesoporous Mater., 2000, 34, 135-147.

47 J. C. Groen, J. A. Moulijn and J. Pérez-Ramírez, J. Mater. Chem., 2006, 16, 2121-2131.

48 D. Verboekend and J. Pérez-Ramírez, Catal. Sci. Technol., 2011, 1, 879.

49 F. Schmidt, M. R. Lohe, B. Büchner, F. Giordanino, F. Bonino and S. Kaskel, Microporous Mesoporous Mater., 2013, 165, 148-157.

50 J. García-Martínez, K. Li and G. Krishnaiah, Chem. Commun., 2012, 48, 11841.

51 J. García-Martínez, M. Johnson, J. Valla, K. Li and J. Y. Ying, Catal. Sci. Technol., 2012, 2, 987.

52 K. Užarević, T. C. Wang, S.-Y. Moon, A. M. Fidelli, J. T. Hupp, O. K. Farha and T. Friščić, Chem. Commun., 2016, 52, 21332136.

53 L. Paseta, E. Simón-Gaudó, F. Gracia-Gorría and J. Coronas, Chem. Eng. J., 2016, 292, 28-34.

54 S. A. Moggach, T. D. Bennett and A. K. Cheetham, Angew. Chem., 2009, 121, 7221-7223.

55 S. Tanaka, K. Kida, T. Nagaoka, T. Ota and Y. Miyake, Chem. Commun., 2013, 49, 7884.

56 M. Oschatz, S. Boukhalfa, W. Nickel, J. T. Lee, S. Klosz, L. Borchardt, A. Eychmueller, G. Yushin and S. Kaskel, J. Mater. Chem. A, 2014, 2, 5131-5139.

57 W. Kroll, US pat., 2205 854, 1940.

58 H. Friedrich, P. E. De Jongh, M. Bulut, S. Van Donk, R. Kenmogne, A. Finiels, V. Hulea and F. Fajula, Angew. Chem., Int. Ed., 2010, 122, 10272-10276.

59 J. Rouquerol, P. Llewellyn and F. Rouquerol, Stud. Surf. Sci. Catal., 2007, 160, 49-56.

60 According to ASTM Int. Standard, Designation, D3906-03 2013, Copyright $($ C ASTM International, 100 Barr Harbor Drive, PO Box C700, West Conshohocken, PA 19428-2959, USA.

61 J. Pérez-Ramírez, D. Verboekend, A. Bonilla and S. Abelló, Adv. Funct.Mater., 2009, 19, 3972-3979. 